\title{
Social Reporting By Indian Banks and Foreign Banks- A Comparative Analysis
}

\author{
Pallavi Sethi \\ Shaheed Bhagat Singh (eve.)College, University of Delhi, India
}

\begin{abstract}
The study provides the level of corporate social responsibility disclosure of the Indian Banking Sector. The purpose of this paper is to investigate the corporate social responsibility (CSR) reporting information of Indian Banks in public as well as private sector as well as foreign banks operating in India and explores the potential effects of financial characteristics on CSR disclosure.The annual reports of all the banks for the year 2009-2010 are examined to analyse the banks' CSR reporting practice. An index comprising of 27 indicators is prepared and each bank's annual report is analysed for the items under the different categories. If a banking company discloses an item of information in the annual report, then "l" will be awarded and if the item is not disclosed then "0" will be awarded. Thereafter each bank's corporate social responsibility reporting index (CSRRI) is measured. It also considers the impact of three financial characteristics viz. profitability, gearing and size. The multiple regressions were used to measure the impact of financial characteristics on banks' CSR reporting initiatives. The results of the study demonstrate that though voluntary, overall CSR reporting by Indian Banks are rather moderate. The results also displayed no significant relationship between gearing and CSR reporting in Indian Banks. Profitability and size of the bank have been found to have significant impact on the CSR reporting. Whereas in case of foreign banks all the factors have a role to play. The study is the primary to investigate CSR reporting practices coupled with the impact of financial characteristics in the specific context of banking sectors in the developing country such as India.
\end{abstract}

Keywords: Social Reporting, Corporate Social Responsibility, Financial Characteristics, CSRRI

CSR is to-day a strategically important and challenging development for business and policy makers taking root in a broad variety of industrial sectors. Environment, safety and health at work are very much an integral part of the CSR concept; companies recognise that they cannot be good externally, while having a poor social performance internally.

Corporate Social Disclosure (CSD) by a firm is intended to demonstrate to the society the social activities that a firm engages in and its impact on the society. Branco and Rodrigues (2006) point out that the business activities impact on various components of the society such as the environment, employee, consumer and local community. It naturally follows that corporate social reporting is information on these topics. It is not surprising that the purpose of corporate social reporting is 'to establish and communicate the social impacts of business actions on those who are affected by them'. The financial sector, too, is beginning to wake up to a range of nonfinancial issues.

Non-financial reporting is an opportunity to communicate in an open and transparent way with stakeholders. In their non-financial reports, firms volunteer an overview of their environmental and social impact during the previous year. The information in non-financial reports contributes to building up a company's risk. The importance of non-financial disclosure in the overall assessment of a company's risk profile is steadily gaining ground.

\section{Mandatory Disclosure Laws}

The Corporations Law and the regulations in India do not explicitly require disclosure of any social information. Disclosure of some social information may occur in the financial statements or the notes to them. Some socially oriented behaviour of corporations has a financial impact and, therefore, disclosure of this will appear in the financial statements.

Many companies do not make any disclosures, in clear contravention of the law. Those companies which do make a disclosure often provided inadequate information to enable readers of the information to make rational decisions. The general consensus is that corporate social reporting degenerates into a public relations exercise that reveals very little of companies' true social performance.

However, internationally there are CSR reporting frameworks i.e. GRI 2002 and AA1000. GRI guidelines are acknowledged for their high-international recognition and influence whereas AA1000 standard for its unique focus on the processes of accountability. 


\section{Csr And Banks}

This study basically deals with corporate social responsibility issues in banking sector. Banks act as financial intermediaries in our society; they price and value financial assets, they monitor borrowers, they manage financial risks and they organize the payment system (Greenbaum and Thakor, 2007).

There is much that banks can do to assist efforts to achieve sustainability. Internal efforts to make day to day operations cleaner, more efficient, and supportive of social structures can help. Integrating environmental and social issues into strategic operations is also important. In this way, financial institutions not only ensure that internal activity is sustainable, but they can also help financing itself become more sustainable. Sustainable finance places importance on the environmental and social consequences of projects and financial products, rather than just the economic impact. This can encompass incorporating environmental and social assessments into financial analysis, or developing products with an explicit environmental and social focus, such as sustainable \& responsible investment (SRI) funds. SRI (socially responsible investment) is an investment strategy that identifies investment targets that carry net environmental and social benefits as well as provide financial growth.

\section{Review Of Literature}

The various studies in relation to social reporting by banks have been done internationally as well as India focusing on the banks of their countries.

\section{INTERNATIONAL STUDIES}

\section{SOCIAL REPORTING BY ISLAMIC BANKS By Bassam Maali, Peter Casson \& Christopher} Napier

This study talks about the social reporting practices adopted by the Islamic banks. Applying the Islamic principles to which the Islamic banks subscribe a benchmark set of social disclosures appropriate to such banks have been developed. They are then compared with the actual social disclosures contained in the annual reports of 29 banks operating according to Islamic principles (located in 16 countries) to this benchmark. The comparison takes the form of a disclosure index measuring the extent to which each bank's social disclosures met the benchmark. In addition, content analysis is undertaken to measure the volume of social disclosures. The results of the analysis suggest that social reporting by Islamic banks falls significantly short of our expectations for entities whose operations are based on Islamic principles. In addition, the banks tend to disclose only those items that help to construct a positive image, such as matters relating to charity and Zakah (an Islamic religious tax).

\section{A Study Of Corporate Social Disclosure In The Finance Sector In Bangladesh Mohammad I. Azim}

This study investigates finance companies' corporate social reporting in Bangladesh, a developing country. A favorable investment climate is one of the preconditions for a country to prosper economically. This can be ensured by good corporate social reporting by finance sector companies. In Bangladesh, finance sector companies together hold $43.82 \%$ of total market capitalization on the Dhaka Stock Exchange and $26.54 \%$ of GDP, which is proportionately large for a country like Bangladesh. Content analysis instruments are used to analyse corporate social reporting by listed finance companies in Bangladesh. Analysis of annual reports published in 2007-2008 reveals that $41 \%$ of listed finance sector companies made some kind of CSR disclosures. As a developing country, this figure is quite impressive compared to CSR disclosures in other sectors, like ceramics, engineering, IT, paper and printing. However, extensive survey of the contents, form, nature and extent of corporate social reporting of finance companies reveals that three quarters of all disclosures are generalized qualitative statements without any attempt at quantification. More than half of disclosures are located in the director's report, and the average length of disclosures amounted to less than half a page.

\section{Reporting On Corporate Social Responsibility By Banks, Financial Institutions And Listed Companies In Poland Gdansk, December 2003}

To identify the awareness of the Corporate Social Responsibility in the Polish banking sector, carried out a survey (from September to October 2003), which covered 31 of 56 commercial banks running operations as at June 2003. Assets of the banks under the analysis constitute over $90 \%$ of all assets of the banking sector. Banks selected for the survey are mostly large privatised domestic banks with the foreign majority. The group also included many banks with $100 \%$ foreign share and the advantage of the Polish capital, as well as banks controlled indirectly by the State Treasury. 


\section{Communication Of Corporate Social Responsibility By Portuguese Banks: A Legitimacy Theory Perspective}

This paper ascertains whether Portuguese banks use their web sites as a medium to disclose social responsibility information and identify what types of this kind of information they disclose, and compare such disclosure with similar disclosure in annual reports. It examines social responsibility information disclosure on the internet by Portuguese banks in 2004 and compares the internet and 2003 annual reports as disclosure media using content analysis. Banks with a higher visibility among consumers seem to exhibit greater concern to improve the corporate image through social responsibility information disclosure. Results thus suggest that legitimacy theory may be an explanation of social responsibility disclosure by Portuguese banks.

\section{Corporate Social Responsibility In The International Banking Industry By Bert Scholtens}

This research paper assesses corporate social responsibility of international banks basically belonging to North America, Europe and pacific region. It develops a framework to assess more than 30 institutions and finds significant differences among individual banks, countries and regions. Furthermore, social responsibility of these banks is compared for the year 2000 and 2005. The findings of the paper show that CSR is an increasingly important issue in the international banking industry. It gets deeper and deeper into the banks business as usual. Furthermore, there are significant changes regarding their relative position with respect to CSR performance.

6. The effect of corporate governance elements on corporate social responsibility (CSR) reporting-Empirical evidence from private commercial banks of Bangladesh Md. HabibUz-Zaman Khan

The purpose of this paper is to investigate the corporate social responsibility (CSR) reporting information of Bangladeshi listed commercial banks and explores the potential effects of corporate governance (CG) elements on CSR disclosure. The annual reports of all private commercial banks (PCB) for the year 20072008 are examined to analyse the banks' CSR reporting practice using content analysis. It also considers three elements of CG such as non-executive directors, existence of foreign nationalities and women representation in the board. The multiple regressions were used to measure the impact of CG elements on banks' CSR reporting initiatives. The results of the study demonstrate that though voluntary, overall CSR reporting by Bangladeshi PCB are rather moderate, however, the varieties of CSR items are really impressive. The results also displayed no significant relationship between the women representation in the board and CSR reporting. Conversely, nonexecutive directors and existence of foreign nationalities have been found the significant impact on the CSR reporting.

\section{INDIAN STUDIES}

\section{1) CSR Initiatives Of Indian Banking Industry-Mahabir Narwal, 2007}

In India this study has been done on the banks in Chandigarh region. Content analysis has been the methodology of the study. The paper's purpose is to highlight the corporate social responsibility (CSR) initiatives taken by the Indian Banking Industry, which can help them to enhance their overall performance. The research is based on the survey questionnaire, administered to 33 public-private sector banks in Northern Haryana, including its capital Chandigarh, which has been analyzed with the help of descriptive statistics and factor analysis. The findings suggest that banks have an objective view-point about CSR activities. They are concentrating mainly on education, balanced growth (different strata of society), health, environmental marketing and customer satisfaction as their core CSR activities. The Indian banking industry is found to be adopting an integrated approach by combining CSR with the ultimate customer satisfaction. Irrespective of location, the nature of CSR activities undertaken by banks is found to be similar.

\section{2) A Survey Of The Extent Of Corporate Social Disclosure: The Case Of Banking Companies In India \\ Mohammed Hossain, Mohmood Ahmed Momin}

The study provides the level of corporate social responsibility disclosure of the Indian banking sector. The purpose of the paper is to ascertain the position of corporate social responsibility in India and especially in banking sector which is practicing as a voluntarily and acts as corporate citizen.The bank in the society plays not an important role in any country but also behave a good citizen. Within this framework 38 banks listed on the Mumbai Stock Exchange have been investigated and only annual report for the year 2002-03 have been considered. The result shows that Indian banks are disclosing considerable amount of social information in the annual reports. The study also reveals that almost 90 per cent of sample banks disclose human resource 
development, staff training and social/community services information. The study at least has given a scenario of the position of corporate social responsibility in India especially in banking sector.

\section{3) CSR AND PERformance: The STORY OF BANKS IN INDIA-SURESH ChANDRA BiHARI \& SUDEEPTA PRADHAN}

There has been an upsurge of socially responsible activities in the Indian corporate sector in the recent past. This research endeavors to map the corporate social responsibility (CSR) practices of major players in the Indian banking sector and finds out the impact of such practices on their performance and image. Based on several published records of CSR activities of major Indian banks in the last few years, the impact of such practices on the performance and image of such banks have been analyzed. The findings suggest that banks in India have increased their CSR activities, which also have a positive impact on performance of the business, apart from improving their image and goodwill. This is reflective of the fact that work done for society may pass on the advantages to the corporate sector and enhance their value. This also sets a good example for other service sectors as well.

\section{4) CSR Practices and CSR Reporting in Indian Banking Sector-Nishi Sharma}

In recent years Corporate Social Responsibility (CSR) has witnessed an astounding ascendancy and resurgence at the global level. The concept of CSR recognizes an organisation's commitment to operate in a socially responsible manner. It takes into consideration the social and environmental implications of corporate financial decisions. Growing complexity of business, increasing concern for sustainable development, need for stewardship of natural resources and call for enhanced transparency have not only magnified the resonance of Corporate Social Responsibility but also heightened the inclination towards integration of CSR principles in the corporate activities. In this regards, actions taken by corporate houses and regulatory authorities operating in developed nations are quite satisfactory. However in developing nations the scenario of CSR activities is not so rosy. Particularly in financial sector there is an absence of stringent provisions regarding compliance and reporting of CSR activities. This has further instigated organisations to remain silent to the issue till any mandatory provision is being enacted. In addition to this the academic publication on this fiery issue also reflects the Western centric nature of research work.

In fact there is an availability of very limited research work in the context of implementation of CSR practices in context to developing nations. In this reference the present paper attempts to analyse CSR practices and CSR reporting in India with special reference to banking sector.

\section{Research Methodology}

To accomplish the objectives of the study, a suitable research methodology has been followed. An index of social disclosure listing the items of information has been designed. Both a weighted disclosure index and an unweighted disclosure index are usually used to determine disclosure level.

We have chosen the unweighted disclosure index methodology. In this case, the key fact is whether or not a company discloses an item of information in the annual report. If a banking company discloses an item of information in its annual report, then ' 1 ' will be awarded and if the item is not disclosed, then ' 0 ' will be awarded. Thus, the unweighted disclosure method measures the Corporate social responsibility reporting index (CSRRI) score of a banking company as additive (suggested by Cooke, 1992) as follows:

$\mathrm{CSRRI}=\mathrm{n} \sum \mathrm{di}$

Where,

$$
\mathrm{i}=1
$$

$$
\begin{aligned}
& \mathrm{d}=1 \text { if the item di is disclosed } \\
& 0=\text { if the item is not disclosed } \\
& \mathrm{n}=\text { number of items }
\end{aligned}
$$

The index of social disclosure constructed in this study consists of 36 items of information including sub-items. The items of information in the Index of Social Disclosure have been classified under different major groups. These groups are listed below:-

I. Environmental policy

II. Codes, reporting and systems

III. Financial products

IV. Society

V. Diversity \& human resource

VI. Customer care 


\section{SELECTION OF SAMPLE BANKS}

In total there are 21 public sector banks and 22 private sector banks and 36 foreign banks. For the purpose of study all these banks have been included i.e. there are 79 banks in all. Cooperative banks have been excluded from the study and the focus has been on the public sector, private sector banks and forign banks.

\section{DATA COLLECTION}

The data collected for the purpose of the study involves the examination of annual reports for the year 2009-2010 of the banks of India. The annual reports of selected banks were examined after downloaded from the respective banks' official web sites. The official web addresses of all firms were collected from the official website of Banking Association Of India. However, incomplete annual reports of some banks were available (only financial information) at the web. Complete reports were collected from the Delhi Headquarters of the concerned banks. As a result, annual reports of the entire population of 79 banks were examined in the study. While firms may exercise other medium of communication for exhibiting CSR reporting such as internet, newspaper, media, this study concentrates on published annual reports.

\section{SELECTION OF STATISTICAL TECHNIQUE}

The second basic objective of the study is to examine the influence of some characteristics on the extent of social disclosure in published annual reports of the banks. The characteristics selected in the study are size of the bank, gearing and profitability.

Statistical Techniques have been used to examine the influence of an independent variable on a dependent variable by many investigators. Multivariate Analysis has been adopted as a statistical technique in the present study to examine the influence of asset size and earnings margin on annual report disclosure.

\section{CSR PERFORMANCE AND FINANCIAL CHARACTERISTICS}

In order to establish the relationship between the extent of social reporting by banks and their financial characteristics namely, size, profitability and gearing the following hypothesis have been generated-

H1: The extent of CSRRI is greater for larger banks(in terms of asset size).

H2: The extent of CSRRI is greater for highly profitable banks.

H3: The extent of CSRRI is greater for highly geared banks.

\section{DESCRIPTIVE STATISTICS}

Table below shows the results of the descriptive analysis of CSR reporting in each broad category of reporting items to measure the banks more keenness of reporting items.

Table I : Descriptive Statistics

\begin{tabular}{|l|l|l|l|l|}
\hline & MINIMUM & MAXIMUM & MEAN & $\begin{array}{l}\text { STANDARD } \\
\text { DEVIATION }\end{array}$ \\
\hline CSRRI & 22.22 & 61.11 & 37.8553 & 8.80604 \\
\hline SIZE & 1013.00 & 9043.00 & 3422.95 & 2299.79 \\
\hline GEARING & 0.00 & 2.33 & 0.9638 & 0.67861 \\
\hline PROFITABILITY & -17.24 & 31.60 & 15.9205 & 10.38256 \\
\hline
\end{tabular}

It is noticeable that the mean of CSRRI and size are 37.8553 and 3422.95 respectively having a range between $61.11 \%$ and $22.22 \%$ for CSRRI. Size ranges from 9043.00 to 1013.00 . There can be seen huge difference in range of gearing and profitability also, having mean of 0.9638 and 15.9205 respectively.

\section{MULTIVARIATE ANALYSIS RESULT}

In this study, regression analysis was used to test the relationship between the various independent variables and the measures of overall CSR reporting.

CSRRI $=B_{0}+B_{1}$ SIZE $+B_{2}$ ROE $+B_{3}$ DRAT $+e_{t}$

Where,

CSRRI is the corporate social responsibility reporting index

SIZE is the size based on total assets

ROE is the profitability on the basis of return on equity

DRAT is the gearing based on Debt to Equity Ratio

$e_{t}$ is the disturbance term

$\mathrm{B}_{0 . \ldots} \mathrm{B}_{3}$ is the Beta coefficient

\section{CORRELATION MATRIX}

Table II represents the correlation matrix for the dependent and independent variables. 
Table II : Correlation Matrix

\begin{tabular}{|l|l|l|l|l|}
\hline VARIABLES & CSRRI & SIZE & GEARING & PROFITABILITY \\
\hline CSRRI & 1 & & & \\
\hline SIZE & 0.296 & 1 & & \\
\hline GEARING & 0.083 & 0.341 & 1 & \\
\hline PROFITABILITY & 0.258 & 0.179 & 0.271 & 1 \\
\hline
\end{tabular}

As can be seen from the table, CSR reporting is positively associated with correlation coefficient of 0.296 to the size of bank, similar to the study's hypothesis. Results also show a positive correlation of 0.258 between CSR reporting and profitability of the bank. However, the correlation coefficient of 0.083 fails to exhibit any confirmation of a univariate association between CSR reporting and gearing.

\section{Result Of Multiple Regression}

Table III shows the results of multiple regressions. As can be seen from the table, the regression model explained $11.7 \%$ of the CSR reporting variance for the explanatory variables. The regression model explains a significant $(\mathrm{p}<0.05)$ relationship between the size variable and extent of CSR reporting. In other words, the greater the size of the bank, the higher the level of social information reported in annual reports. This finding supports the study's $\boldsymbol{H} \mathbf{1}$.

TABLE III : Results of Regression Analysis

\begin{tabular}{|l|l|l|l|l|}
\hline Variables & Coefficient value & t-value & p-value & VIF \\
\hline Size & 0.297 & 1.767 & 0.001 & 1.034 \\
\hline Gearing & 0.42 & 1.807 & 0.079 & 1.080 \\
\hline Profitability & 0.077 & 0.540 & 0.002 & 1.115 \\
\hline $\mathbf{R}^{2}$ & 0.117 & & \\
\hline Adjusted R & \\
\hline F statistics & 0.0976 & & \\
\hline
\end{tabular}

Large banks make more CSR reporting because of accountability and visibility. They have more shareholder base and stakeholder's to whom they are accountable and hence require disclosing more about their social responsibilities. The profitability of the bank, represented by the return on equity, is significantly related $(\mathrm{p}=0.002)$ with the level of CSR reporting and thus provides evidence for accepting $\boldsymbol{H} 2$. Profitable companies disclose more in order to legitimize their actions in front of the society and to convey their image. However, the result does not support $\boldsymbol{H 3}$ as gearing is not statistically significant $(\mathrm{p}>0.05)$. This is inconsistent with some of the earlier studies which have established a significant relationship between the two variables. One of the reasons that can be attributed to this is the lack of any guidelines for the preparation of social reports or for reporting social activities.

\section{SECTOR-WISE ANALYSIS}

For the purpose of sectoral analysis, public and private sector banks have been combined and named as Indian banks and the other sector is of the foreign banks.

By analyzing the effect of the independent variables on Indian banks and foreign banks, we get the following results-

\section{FOREIGN BANKS}

Table IV: Correlation Matrix(Foreign Banks)

\begin{tabular}{|c|c|c|c|c|}
\hline VARIABLES & CSRRI & SIZE & GEARING & PROFITABILITY \\
\hline CSRRI & 1 & & & \\
\hline SIZE & 0.091 & 1 & & \\
\hline GEARING & 0.657 & 0.534 & 1 & \\
\hline PROFITABILITY & 0.018 & 0.126 & 0.035 & 1 \\
\hline
\end{tabular}

A look at the table IV reveals that size, gearing and profitability are positively related to CSRRI but the significance of correlation varies amongst the three variables. While a correlation coefficient of 0.657 shows a significant positive correlation between CSRRI and gearing, it points out towards the fact that in foreign banks gearing plays a very important role in the extent of disclosure by the banks. Highly geared banks exhibit their social responsibility activities in order to give sanctity to their activities and to justify their expenditure.

On the other hand, correlation coefficient of 0.091 and 0.018 between CSRRI and size and CSRRI and profitability respectively, fails to exhibit any significant correlation amongst the variables. 


\section{MULTIPLE REGRESSION ANALYSIS}

The following table summarizes the results of the multiple regression analysis performed on the foreign banks.

Table V: Result of Regression Analysis (Foreign Banks)

\begin{tabular}{|l|l|l|l|l|}
\hline Variables & Coefficient value & t-value & p-value & VIF \\
\hline Size & 0.435 & 0.765 & 0.762 & 3.618 \\
\hline Gearing & 0.512 & 3.852 & 0.013 & 2.752 \\
\hline Profitability & 0.078 & 0.170 & 0.709 & 4.881 \\
\hline $\mathbf{R}^{2}$ & 0.325 & & \\
\hline Adjusted $\mathbf{R}^{\mathbf{2}}$ & 0.097 & & \\
\hline F statistics & 1.750 and $\mathrm{p}=0.002$ & & \\
\hline
\end{tabular}

The value of $\mathrm{R}^{2}$ equals 0.325 indicating that $32.5 \%$ of the variations in the social reporting are explained by the size, gearing and profitability. Gearing significantly influences the extent of social reporting by foreign banks as is evident from the p-value 0.073. The significance of coefficient is significant if the p-value is less than or equal to the level of significance (alpha), which is assumed to be 0.05 in the present case. On the other hand, size and profitability have no significant effect on the social reporting by banks as p-value is 0.762 and 0.709 which is far greater than 0.05 .

INDIAN BANKS

Correlation as well as Multivariate Analysis was computed for Indian banks(private and public sector) also and the results are as follows-

\section{CORRELATION MATRIX}

Table VI: Correlation Matrix (Indian Banks)

\begin{tabular}{|l|l|l|l|l|}
\hline VARIABLES & CSRRI & SIZE & GEARING & PROFITABILITY \\
\hline CSRRI & 1 & & & \\
\hline SIZE & 0.431 & 1 & & \\
\hline GEARING & 0.237 & 0.148 & 1 & \\
\hline PROFITABILITY & 0.549 & 0.208 & 0.074 & 1 \\
\hline
\end{tabular}

An analysis of the table VI indicates that there exists a positive correlation between CSRRI and size, gearing and profitability. There exists a significant correlation between reporting initiatives by bank and their size , gearing and profitability $(0.431,0.237$ and 0.549 respectively). Thus, for Indian banks, size, gearing and profitability, all factors play a major role in determining the extent of disclosure. One of the reasons that could be cited is that size of the bank compels the bank to disclose more and high profitability makes them legitimize their actions. Gearing compels the banks to legitimize their actions in front of their creditors.

MULTIPLE REGRESSION ANALYSIS

The results of multiple regression analysis have been summarized in the table given below-

Table VII: Result of Regression Analysis (Indian Banks)

\begin{tabular}{|l|l|l|l|l|}
\hline Variables & Coefficient value & t-value & p-value & VIF \\
\hline Size & 0.283 & 1.083 & 0.0194 & 1.786 \\
\hline Gearing & 0.078 & 0.165 & 0.0342 & 1.112 \\
\hline Profitability & 0.328 & 0.396 & 0.0476 & 2.759 \\
\hline $\mathbf{R}^{\mathbf{2}}$ & 0.876 & & \\
\hline Adjusted $\mathbf{R}^{\mathbf{2}}$ & 0.045 & & & \\
\hline F statistics & 0.728 and $\mathrm{p}=0.001$ & & \\
\hline
\end{tabular}

As can be analysed from the table, value of $\mathrm{R}^{2}$ equals to 0.876 indicating that $87.6 \%$ variations in social reporting are explained by size, gearing and profitability. The value of $\mathrm{R}^{2}$ is significant as indicated by the $\mathrm{p}$ value (0.001) of F-statistic. Size, gearing and profitability significantly influence social reporting by banks as is evident from their p-value i.e. $0.0194,0.0342$ and 0.0476 respectively. In all the cases p-value is less than 0.05 i.e. the level of significance.

Tests of non-linearity and heteroskedasticity of the data through an analysis of residuals indicated no major problem for regression analysis. Residuals are what are left over after the model is fit and they are also the difference between the observed value of the dependent variable and the value predicted by the regression line. Further, the visual examination of correlation matrix of the explanatory variables is thought of an essential way to perceive collinearity problem. Correlation coefficient is considered problematic if it exceeded 0.8. A more precise and indicative method broadly used is the VIF for each of the independent variable. Co-linearity is considered a problem if the VIF exceeds ten. Thus, based on correlation matrix and VIF found in the study it is unlikely that multicollinearity is to influence the regression results, since the highest VIF of 4.881 is far less than the threshold of ten. 


\section{Conclusions}

There is a need for mandatory and comprehensive corporate social reporting. Banks are using the lack of mandatory regulation to manipulate information about their true social performance which deflects potential criticism and activism.

Hopefully, corporate social reporting will become more comprehensive, comparable and thus less prone to manipulation. Over time it is possible to observe the same happening with financial accounting, which is continuing to mature, particularly with the evolving body of rules set out in the accounting standards. As a voluntary exercise it will simply languish as a public relations tool, rather than being a serious obligation for which corporations and managers should be accountable.

\section{Books \& Journals}

\section{References}

[1]. Albuquerque, P., Bronnenberg, B., Corbett, C. (2007) A Spatio-temporal Analysis of Global Diffusion of ISO Certification, Management Science, vol. 53, no. 3: 451-468

[2]. Altenburger, O., Schaffhauser-Linzatti, M. (2007) About scope and focus of notes - a new approach to highlight intangibles, 30th Annual Congress of European Accounting Association, http://www.licom.pt/eaa2007/papers/EAA2007_1086_final.pdf

[3]. Association of Chartered Certified Accountants (ACCA) (2001) Environmental, Social and Sustainability Reporting on the World Wide Web: A Guide to Best Practice, Certified Accountants Educational Trust, London

[4]. Beattie, V., Mc Innes, B., Fearnley, S. (2004) A methodology for analysing and evaluating narratives in annual reports: a comprenhensive descriptive profile and metrics for disclosure quality attributes, Accounting Forum, no. 28: 205-236

[5]. Belal, A.R. (2001), “A study of corporate social disclosures in Bangladesh”, Managerial Auditing Journal, Vol. 16 No. 5, pp. 27489.

[6]. Beretta, S., Bozzolan, S. (2004) A framework for the analysis of firm risk communication, The International Journal of Accounting, vol. 39, no. 3: 289-295

[7]. Bhanumurthy, k.v. (2007). Business Ethics and Corporate Responsibility - A New Perspective. WORKSHOP ON ISO 26000 Guidance on Social Responsibility and the implications for Developing Countries. delhi.

[8]. Cooper S.M., Owen D.L. (2007) Corporate social reporting and stakeholder accountability: The missing link, Accounting, Organizations and Society, vol. 32, no. 7-8: 649-667

[9]. Department of Trade and Industry (2004) Draft Regulations on the Operating and Financial Review and Directors' Report: A Consultative Document, Department of Trade and Industry, London

[10]. Epstein, M.J., Birchard B. (1999) Counting What Counts: Turning Corporate Accountability Into Competitive Advantage, Reading, MA Perseus Books

[11]. F. M., Sroufe, R., \& Narasimhan, R. (2007). An examination of corporate reporting, environmental management practices and firm performance. journal of operations management, 998-1014.

[12]. Fédération des Experts Comptables Européens (FEE) (2000), Towards a Generally Accepted Framework for Environmental Reporting, www.fee.be

[13]. Gary, S. (2005) Meeting the challenge of performance reporting under the EU Accounts Modernisation Directive, FSN Publishing Limited, London

[14]. Global Reporting Initiative (GRI) (2002), Sustainability Reporting Guidelines, www.globalreporting.org

[15]. Gray R. (2002) The social accounting project and Accounting Organizations and Society Privileging engagement, imaginings, new accountings and pragmatism over critique?, Accounting, Organizations and Society, Vol. 27: 687-708

[16]. Gray, R., Owen, D., Adams C. (1996) Accounting and accountability, Hemel Hempstead, Prentice Hall PH

[17]. Gray, R.H., Kouhy, R., Lavers, S. (1995): Corporate social and environmental reporting: A review of the literature and a longitudinal study of UK disclosure, Accounting, Auditing and Accountability Journal, Vol. 8, No. 2: 47-77

[18]. Guthrie, J., Cuganesan, S., Ward, L. (2007) "Industry specific social and environmental reporting: The Australian Food and Beverage Industry", Accounting Forum, In Press Available online 3 December 2007

[19]. Hannele, M. (2008) Construction of the social dimension of CSR in corporate disclosures, paper presented at 20th International Congress On Social And Environmental Accounting Research 2008, University of St Andrews, http://lipas.uwasa.fi/ktt/lasktoim/tuto2008/MakelaHanneleTuto2008.doc

[20]. Harrison, G.L., McKinnon, J.L. (1986) Culture and accounting change: A new perspective on corporate reporting regulation and accounting policy formulation, Accounting, Organizations and Society, Vol. 11, no. 3: 233-252

[21]. Ite, U. (2004) Multinationals and corporate social responsibility in developing countries: a case study of Nigeria, Corporate Social - Responsibility and Environmental Management, Chichester, Mar. Vol. 11, no. 1: 1 -12

[22]. Jackson, R., Quotes, P. (2002) Environmental, Social and Sustainability Reporting on the Web: Best Practices, Corporate Environmental Strategy, Vol. 9, no. 2: 193-202

[23]. Julian Blanchard, 'Corporate Social Reporting' (1998) 23 Alternative Law Journal Carnevale, C., Mazzuca, M. and Venturini, S. (2011), Corporate Social Reporting in European Banks: The Effects on a Firm's Market Value. Corporate Social Responsibility and Environmental Management

[24]. Kolk, A. (2008) Sustainability, Accountability and Corporate Governance: Exploring Multinationals' Reporting Practices, Business Strategy and the Environment, Volume 18:1-15

[25]. Line M., Hawley H., Krut R. (2002) The Development of Global Environmental and Social Reporting, Corporate Environmental Strategy, Vol.9, no. 1: 69-78

[26]. Lori Holder-Webb, J. R. (2009). The Supply of Corporate Social Responsibility Disclosures Among U.S. Firms. Journal of Business Ethics, 497-527.

[27]. Lungu, C.I., Caraiani, C., Dascalu, C., Guse, R.G. (2009) Critical interpretation study of social and environmental aspects presented in accounting ISI journals, 4th Annual Conference Accounting and Management Information Systems, Bucharest

[28]. Mahabir Narwal(2007), “CSR initiatives of Indian Banking Industry, Social responsibility Journal, Vol. 3, Issue 4, pp 49-60

[29]. Moneva, J.M., Archel, P., Correa, C. (2006) GRI and the camouflaging of corporate unsustainability, Accounting Forum Vol. 30 , no. 2: 121-137

[30]. Nishi Sharma, “CSR Practices and CSR Reporting in Indian Banking Sector”, IJAEBA, Vol. No.1, Issue No.2, 056-066 
[31]. O'Dwyer, B. (2002) Managerial perceptions of corporate social disclosure. An Irish story, Accounting, Auditing \& Accountability Journal, Bradford. Vol. 15, Issue 3: 406-437

[32]. O'Donovan, GM and Armstrong, A and Fitzpatrick, M and Sweeney, M, Australian Banks as Corporate Citizens: Are They Toeing the Triple Bottom Line?, 3rd Asia Pacific Interdisciplinary Research Association Conference Proceedings, 15-17 July, 2001, Adelaide, South Australia EJ (2001)

[33]. Owen, D. (2008) Chronicles of Wasted time? A personal reflection on the current state of, and future prospects for, social and environmental accounting research, Accounting, Auditing \& Accountability Journal, Vol. 21, No. 2: 240-267

[34]. Pedwell, K. (2004) A Comparative Analysis of Corporate Social Responsibility Reporting In Developed and Developing Countries, Annual Congress of European Accounting Association, Prague

[35]. Rahaman, A.S., Lawrence, S., Roper, J. (2004) Social and environmental reporting at the VRA: institutionalised legitimacy or legitimation crisis?, Critical Perspectives on

[36]. Runhaar, H., \& Lafferty, H. (2009). Governing Corporate Social Responsibility: An Assessment of the Contribution of the UN Global Compact to CSR Strategies in the Telecommunications Industry. Journal of Business Ethics, 479-495.

[37]. Scholtens B. 2009. Corporate social responsibility in the international banking industry. Journal of Business Ethics 86: $159-175$.

[38]. Solomon, A., Lewis, L. (2002) Incentives and disincentives for corporate environmental disclosure, Business Strategy and the Environment, May/Jun: 154-169

[39]. Victoria Wise and Muhammad Mahboob Ali (2009). Corporate Governance and Corporate Social Responsibility in Bangladesh with special reference to Commercial Banks. AIUB Bus Econ Working Paper Series, No 2009-05

[40]. Weiss A., Scheiwiller T. (1999) Discussion Paper: Ideas on GRI Report Verification, PriceWaterhousCoopers, August

\section{Websites}

- www.globalreporting.org

- www.rbi.org.in

- www.iba.org.in

- websites of all the banks under study 